\title{
Validation of VX2 as a Hepatocellular Carcinoma Model: Comparison of the Molecular Reaction of VX2 and HepG2 Tumor Cells to Sorafenib In Vitro
}

\author{
NORBERT NASS ${ }^{1}$, SEBASTIAN STREIT ${ }^{2}$, CHRISTIAN WYBRANSKI ${ }^{2,3}$, JULIAN JÜRGENS ${ }^{2}$, \\ JAN BRAUNER ${ }^{2}$, NADINE SCHULZ ${ }^{2}$, MACIEJ POWERSKI ${ }^{2}$, JENS RICKE ${ }^{2,4}$, \\ THOMAS KALINSKI ${ }^{1}$, OLIVER DUDECK ${ }^{2,4,5}$ and MAX SEIDENSTICKER ${ }^{2,4}$ \\ ${ }^{1}$ Institute of Pathology, and ${ }^{2}$ Department of Radiology and Nuclear Medicine, \\ Otto von Guericke University Magdeburg, Magdeburg, Germany; \\ ${ }^{3}$ Institute of Diagnostic and Interventional Radiology, University Hospital of Cologne, Cologne, Germany; \\ ${ }^{4}$ International School of Image-Guided Interventions, Magdeburg, Germany; \\ ${ }^{5}$ Hirslanden Private Hospital Group, Radiology Clinic, Centre for Microtherapy, Zurich, Switzerland
}

\begin{abstract}
As there is currently no superior hepatocellular carcinoma (HCC) model with percutaneous vascular access for transarterial treatments available, the VX2 rabbit model is frequently used for in vivo investigations on liver carcinoma. However, the VX2 cell line was derived from a virus-induced skin papilloma that can form carcinosarcoma in liver of rabbits and the transferability of obtained results to HCC treatment remains open. Here we compared the most frequently investigated human HCC model cell line, HepG2, with VX2 cells in vitro in terms of sensitivity towards the broad specificity kinase inhibitor sorafenib and responsiveness to the addition of platelet-derived growth factor $A B$ (PDGF$A B)$, vascular endothelial growth factor (VEGF) and hepatic growth factor (HGF), as well as insulin and interleukin-1 $\beta$ $(I L 1 \beta)$. Phosphorylation of protein kinase $B$ (AKT) the mitogen-activated protein kinases (MAPKs) p38 and p42/44 (extracellular signal-regulated kinase, ERK1/2) and inhibitor of kappa light chain gene enhancer alpha (IKB $\alpha)$ was determined by western blotting as these events are associated with early signaling cascades. Additionally, the inhibition of phosphorylation under sorafenib treatment was investigated. Sorafenib was equally toxic to both cell lines, but only in HepG2 was activation of caspase 3/7 activity, as a sign of apoptosis, observed. VX2 cells exhibited generally more intense phosphorylation signals in response to the growth
\end{abstract}

Correspondence to: Norbert Nass, Otto von Guericke University Magdeburg, Institute of Pathology, Magdeburg, Germany. Tel: +49 3916117876, Fax: +49 3916715818, e-mail: norbert.nass@med.ovgu.de

Key Words: VX2, HepG2, hepatocellular carcinoma, sorafenib, in vitro models, protein kinase $\mathrm{B}(\mathrm{ACT})$, mitogen activated protein kinase (MARK). factors and also serum. In contrast to VX2, HepG2 cells showed no response to PDGF-AB or VEGF as determined by kinase phosphorylation. In both cell lines, sorafenib inhibited growth factor-induced phosphorylation of ERK and p38MAPK. AKT phosphorylation was only inhibited in VX2 cells and $I_{k} B \alpha$ phosphorylation was not influenced by this kinase inhibitor in either cell type. Taken together, the two cellular models for HCC share several features related to sorafenib application, but differed in their responsiveness towards growth factors. Therefore, results obtained with the VX2 model cannot be extended to human HCC without appropriate caution.

The treatment of hepatocellular carcinoma (HCC) remains a challenge: the incidence is rising worldwide and the disease is still frequently diagnosed in an advanced stage at which curative treatment cannot be provided. Potentially curative liver transplantation is restricted to a minor proportion of these patients. Furthermore, long-term survival from resection or local ablation by radiofrequency can only be performed at very early and early stages of disease [according to the Barcelona Clinic Liver Cancer (BCLC) scheme] (1-4). Transarterial chemoembolisation (TACE) is accepted as the therapy of choice in selected patients within the intermediate disease stage (BCLC B) or as bridging treatment for patients on the waiting list for transplantation $(1,2,5-7)$. When TACE is contraindicated, as well as in advanced disease, systemic therapy with sorafenib, a multikinase inhibitor, is the only available effective treatment (8). Radioembolization with ${ }^{90} \mathrm{Y}$ as alternative or additive treatment at this stage of disease is currently under investigation in large phase III trials (9).

Through its embolic effect, TACE may induce the release of angiogenic factors, which in turn may promote growth of surviving tumor cells leading to tumor recurrence and 
metastatic spread. Therefore, combining TACE with systemic sorafenib treatment is an attractive concept $(10,11)$. However, clinical data on this issue so far are inconclusive $(12,13)$. In order to enhance the adjunctive effect of sorafenib combined with TACE and to reduce the sideeffects of systemic sorafenib therapy, local application of sorafenib into the $\mathrm{HCC}$, together with embolic material, is proposed and under initial preclinical research, with promising results (14-18).

The common preclinical TACE model is the VX2 tumorbearing rabbit model $(14,15,17,19,20)$. VX2 is a virusinduced papilloma transforming to an aggressive anaplastic carcinosarcoma of the rabbit and unfortunately no hepatoma model for the rabbit (as for rats or mice) exists $(21,22)$. However, due to percutaneous vascular accessibility in the rabbit and a pattern of vascularization similar to HCC, VX2 is a widely accepted model of HCC for TACE treatment (16, 20, 23). It remains unclear whether data drawn from the VX2 model can be adopted for HCC treatment, especially if complex and specifically acting substances such as sorafenib are used. Data on in vitro comparison of VX2 to hepatoma cells is very scarce. In one study the glucose metabolism of VX2 was compared to that of hepatoma cells (AS-30D), showing a comparable pattern of glucose utilization and metabolization (24).

Recently, a comparison of the sensitivity of the VX2 and HepG2 cell lines to chemotherapeutic agents was published (25). It was found that sensitivity to doxorubicin, mytomicin$\mathrm{C}$, sunitinib, sorafenib and lapatinib was similar, whereas the toxicity of platins and irinotecan in particular clearly differed between the cell lines.

To our knowledge, there is no study focusing on the molecular reaction of $\mathrm{VX} 2$ cells to sorafenib. In order to further elucidate if the VX2 model can serve as a valuable HCC paradigm when sorafenib is applied, we sought to compare the molecular response of VX2 cells to those of HepG2 cells under sorafenib exposure in vitro. As study parameters, cell viability/proliferation, apoptosis (as caspase $3 / 7$ activity) and phosphorylation of kinases representing the nuclear factor kappa-light-chain-enhancer of activated Bcells $(\mathrm{NF}-\mathrm{kB})$ pathway [inhibitor of kappa light chain gene enhancer alpha $(\mathrm{I} \mathrm{KB} \alpha)$ ], proliferative responses [protein kinase B (AKT) and extracellular signal-regulated kinases (ERK1/2)] were chosen (26).

\section{Materials and Methods}

Cell lines, growth factors and sorafenib. VX2 cells were obtained from IAZ (Munich, Germany) and the HepG2 cell line was obtained from the American Type Tissue Collection (ATCC) stock center. Both cell lines were maintained in RPMI-1640 medium supplemented with fetal calf serum (FCS; 10\%) and penicillin/streptomycin (Biochrom, Berlin, Germany) at $37^{\circ} \mathrm{C}$ in a humidified cell culture incubator (Heraeus, Hanau, Germany) in
$5 \% \mathrm{CO}_{2}$. Cells were supplied with fresh medium every 3 days and transferred weekly after detachment with trypsin/EDTA (Biochrom, Berlin, Germany). All cell culture dishes, plates and flasks were from TPP (Trasadingen, Switzerland). Hepatic growth factor (HGF), vascular endothelial growth factor (VEGF) and interleukin$1 \beta$ (IL1 $\beta$ ) were from Miltenyi-Biotech (Bergisch-Gladbach, Germany); insulin was from Sigma Aldrich (Taufkirchen, Germany); platelet-derived growth factor (27) was from Professor Hoppe (Würzburg, Germany); sorafenib tosylate was provided by Bayer (Berlin, Germany).

Cell stimulation and western blotting. For stimulation with different growth factors, cells were seeded into 24-well plates and grown to confluence. The medium was then removed, the cells washed with serum-free medium and further incubated in serum-free (HepG2) or serum-reduced $(0.5 \%$; VX2) medium for $24 \mathrm{~h}$. Before stimulation, either sorafenib dissolved in dimethyl sulfoxide (DMSO) or solvent (final DMSO concentration 0.1\%) was added for 90 minutes preincubation. Effectors were then added $(10 \mathrm{ng} / \mathrm{ml} \mathrm{IL1} \beta, 20 \mathrm{ng} / \mathrm{ml}$ VEGF, $100 \mathrm{nM}$ insulin, $10 \mathrm{ng} / \mathrm{ml}$ PDGF-AB, 2.5 to $100 \mathrm{ng} / \mathrm{ml} \mathrm{HGF)}$ and after 10 minutes, the medium was aspirated and the cells lysed with $50 \mu \mathrm{l}$ SDS-lysis buffer [50 mM TRIS/Cl pH 6.8, 2\% sodium dodecyl sulfate (SDS), protease and phosphatase inhibitors (1/100; Sigma-Aldrich)]. The plates were stored at $-20^{\circ} \mathrm{C}$ until lysates were transferred into tubes and denaturing sample buffer was added. SDSpolyacrylamide electrophoresis was performed on $12 \%$ polyacrylamide (PAA) gels and proteins were transferred to nitrocellulose filters $(0.45$ $\mu \mathrm{m}$;Whatman-GE-Life Sciences, via VWR, Darmstadt, Germany) by tank blotting (BioRad, Munich, Germany) as previously described (28, 29). Blots were stained with Poinceau Red (Sigma-Aldrich) to control transfer quality and then blocked in TBS (50 mM TRIS/Cl pH 7.4150 $\mathrm{mM} \mathrm{NaCl}$ ), containing $2 \%$ bovine serum albumin (BSA; SigmaAldrich), NP-40 (0.2\%; Applichem, Darmstadt, Germany) and sodium azide $(0.03 \%)$ for $1 \mathrm{~h}$ at room temperature. Blots were incubated with primary antibodies in blocking buffer overnight at $4^{\circ} \mathrm{C}$. Antibodies directed against the phosphorylated proteins (AKT, ERK1/2 and IKB $\alpha$ ) were from Cell Signaling (via NEB, Frankfurt, Germany), $\beta$-actin monoclonal mouse antibody was obtained from Sigma-Aldrich. After washing three times with TBS (0.2\% BSA; $0.2 \%$ NP-40), horseradish peroxidase conjugated secondary antibody (DAKO, Hamburg, Germany) was applied for $1 \mathrm{~h}$ at room temperature in washing buffer. After three further washes, detection was performed by chemoluminescence with ECL Plus reagent (Millipore, Darmstadt, Germany) in a GeneGnome imaging system (Syngene, Cambridge, UK). Signals were quantified by using ImageJ (30) and normalized to the $\beta$-actin signal.

Cell viability and caspase assay. Cell viability and proliferation as well as caspase assays were performed as described previously (29). For cell viability assays, cells were seeded into 24-well plates (Greiner, Frickenhausen, Germany) at about $30 \%$ confluence in full medium. The next day, sorafenib or solvent was added. After $72 \mathrm{~h}$, resazurin (Sigma-Aldrich) was added (10 $\mu \mathrm{g} / \mathrm{ml}$ final concentration) and the cells incubated for 30 to $120 \mathrm{~min}$ at $37^{\circ} \mathrm{C}$, depending on color development. Then the fluorescence of $100 \mu \mathrm{l}$ supernatant was determined in a 96-well plate at wavelengths 525/580-640 nm (excitation/emission, fluorescence module 'green') in a Glomax microtitre plate reader (Promega, Mannheim, Germany). Data were normalized to the fluorescence signal obtained for control solventtreated cells. 


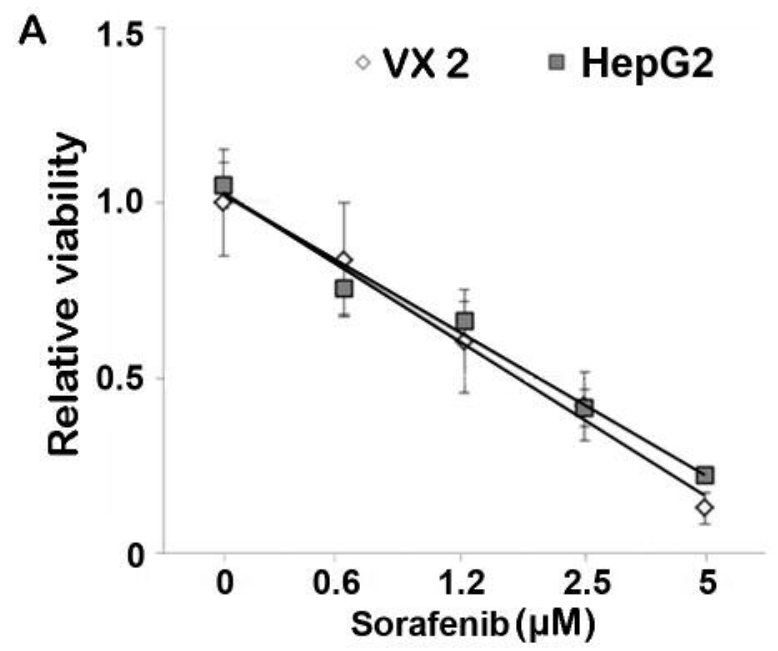

B

Figure 1. A: Toxicity of sorafenib. Cells were grown in full medium supplemented with sorafenib or solvent (dimethyl sulfoxide) for 72 h. Viability/proliferation was determined by the resazurin assay. B: Activation of caspase 3/7 as determined by a luminogenic enzyme assay. Cells were incubated for the indicated time with sorafenib, then lysed and the caspase 3/7 activity determined as described in the Materials and Methods section. *Significantly different between the two cell lines $(p<0.05)$.

For caspase 3/7 determinations, cells were seeded into 96-well plates at about $50 \%$ confluence. The next day sorafenib was added and the caspase activity was measured at $0,2,4$ and $6 \mathrm{~h}$ using the caspase 3/7-glo luminescence assay system (Promega). Luminescence was read in a Glomax multidetection system (Promega). Data were expressed relative to control treatments for each cell line.

Statistical calculation. Experiments were at least performed three times with each treatment in duplicate. All calculations were performed with SPSS vers. 22 (IBM, Ehningen, Germany). Data are presented as mean \pm standard error (SEM). Tests for significant differences of means of the results for the two cell lines were performed using ANOVA with post hoc Tamhane T2 test. A value of $p<0.05$ was considered significant.

\section{Results}

Toxicity of sorafenib. Firstly, the toxicity of sorafenib towards the two cell lines was determined. According to a previously described method (31), we incubated the cells in full medium with and without sorafenib or DMSO for $72 \mathrm{~h}$. Viability together with proliferation was determined by this approach. HepG2 and VX2 cells both exhibited an half-maximal effective concentration $\left(\mathrm{EC}_{50}\right)$ value of about $1.8 \mu \mathrm{M}$ (Figure 1A). To examine the type of cell death, we performed additional caspase 3/7 assays in sorafenib-treated cells. Only HepG2 cells responded significantly by activation of this effector caspase of responded apoptosis (Figure 1B).

Cell response to different stimuli. In the next set of experiments, we stimulated the two cell lines with several agents, including serum, growth factors and IL1 $\beta$. For this, the cells were grown to confluence and subjected to serum starvation for $24 \mathrm{~h}$. Such resting cell populations exhibit low kinase activities, and thus are able to respond to stimuli without interference from serum and proliferation. As the VX2 cell line did not tolerate complete serum removal, the serum starvation was performed with the lowest tolerable amount of FCS, namely $0.5 \%$. Firstly, we determined the optimal inhibitory concentration of sorafenib for ERK phosphorylation in unstimulated and serum-stimulated cells (Figure 2). Significant inhibition was observed at a sorafenib concentration of $2.5 \mu \mathrm{M}$ and higher. HepG2 cells seemed slightly less sensitive, but this was not statistically significant. We therefore continued with $5 \mu \mathrm{M}$ sorafenib for the investigation of this inhibitor on growth factor responses. This concentration resulted in $60 \%$ and $40 \%$ reduction of ERK phosphorylation in VX2 and HepG2, respectively (Figure 2).

We observed that VX2 cells generally responded more strongly to most of the stimuli provided, with rapid phosphorylation of AKT, p38 MAPK and ERK (p42/44 MAPK) (Figure 3). In detail, ERK and p38 MAPK phosphorylation was induced with FCS, PDGF-AB, insulin, IL1 $\beta$ and VEGF. Additionally, strong phosphorylation of AKT was observed in response to serum and PDGF-AB. IL1 $\beta$ also caused phosphorylation of $\operatorname{IkB} \alpha$, indicating activation of the NFKB pathway. ERK, AKT and p38 phosphorylation was nearly completely inhibited by sorafenib $(5 \mu \mathrm{M})$. No effect of sorafenib on $\operatorname{IkB} \alpha$ phosphorylation was observed. HepG 2 cells showed only a weak response to serum, without p38 phosphorylation, and 

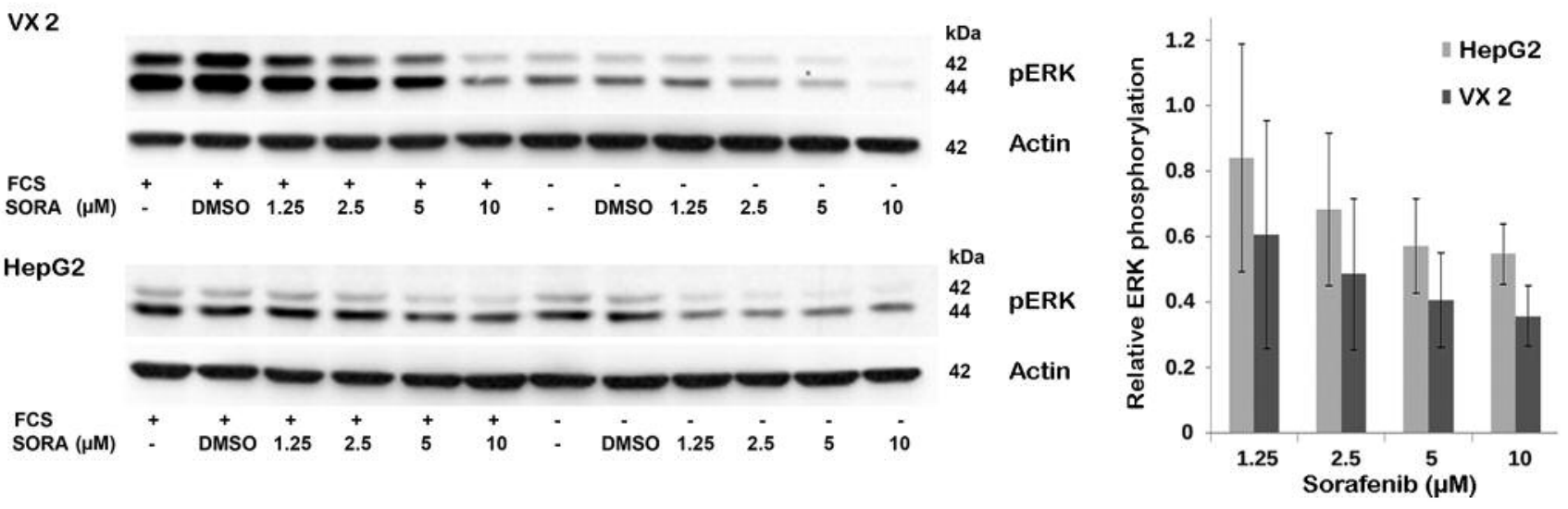

Figure 2. Dose response of extracellular signal-regulated kinase phosphorylation ( $p E R K$ ) to sorafenib (SORA). Cells were serum-starved for $24 \mathrm{~h}$ and then preincubated with different sorafenib concentrations as indicated for $1 \mathrm{~h}$. Cells were then stimulated by adding 5\% fetal calf serum (FCS) for 10 min and proteins were analyzed by western blotting as described in Material and Methods. Experiments were performed in triplicate and a representative result is shown. Intensity of pERK signals was normalized to the actin loading control and control cell samples set to 1. These doseresponse data are quantitatively shown as a bar graph (right).

VX 2

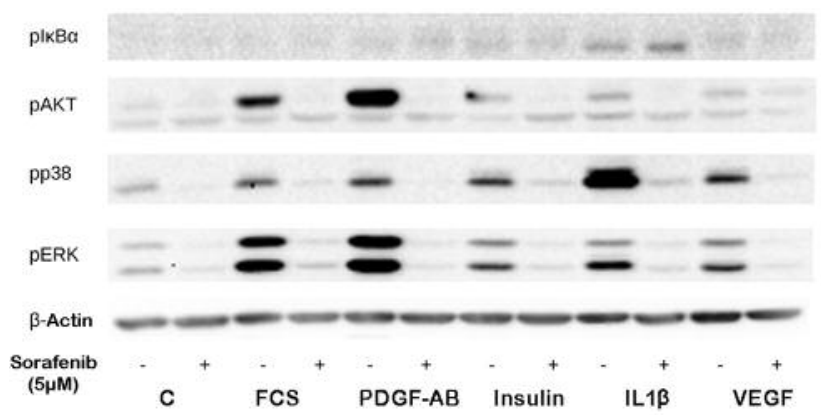

HepG2

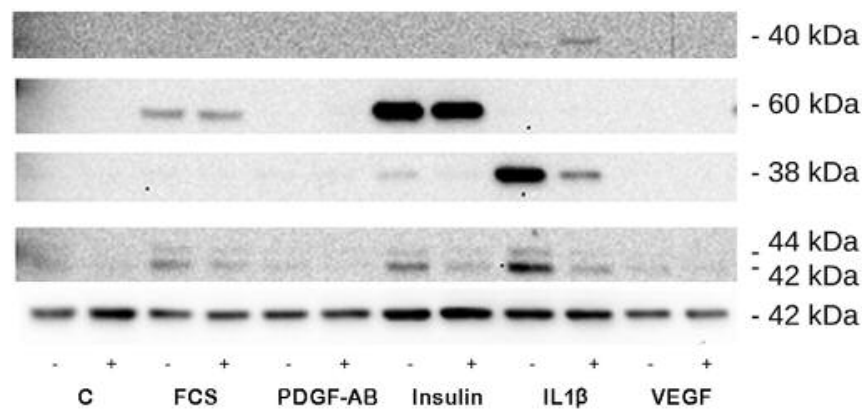

Figure 3. Signaling-associated phosphorylation of protein kinases. Cells were stimulated for 10 min after 24-h serum starvation as described in the Materials and Methods. Protein phosphorylation was detected bywestern blotting. Experiments were performed in triplicate with one representative result shown. Concentration of stimulatory agents was $5 \%$ fetal calf serum (FCS), $10 \mathrm{ng} / \mathrm{ml}$ platelet-derived growth factor AB (PDGF-AB), $100 \mathrm{nM}$ insulin, $10 \mathrm{ng} / \mathrm{ml}$ interleukin-1 $\beta$ (IL1 $\beta$ ) and $20 \mathrm{ng} / \mathrm{ml}$ vascular endothelial growth factor (VEGF).

apparently no response to PDGF-AB and VEGF. Insulin, in contrast, caused a much stronger response than in VX2 cells, especially of AKT phosphorylation. Whereas sorafenib inhibited ERK and p38 phosphorylation, no effect on AKT was seen.

For HGF, similar responses were seen in both cell lines, however, VX2 was again more sensitive, as shown by a dose-response experiment (Figure 4).

\section{Discussion}

In this study, we compared two frequently used models for HCC: the VX2 rabbit model, which is often used for in vivo studies, and the HepG2 cell line, which is regularly used for in vitro studies. We focused on the kinase inhibitor sorafenib, as this compound is an important drug for treatment of patients with HCC. Furthermore, it has become the focus of interest as it was recently applied in combination with transarterial chemoembolization (TACE) in preclinical series (14-18).

The VX2 cell model is currently the only rodent model system with percutaneous transarterial accessibility for studying locoregional treatment of HCC in vivo. However, its origin from skin papilloma suggests that these carcinosarcoma cells do not behave exactly as would be expected for liver cell carcinomas. However, others have pointed out that VX2 cells are as sensitive as HepG2 cells to a variety of chemotherapeutic agents, although some significant differences were found $(23,25)$. Indeed, here we also determined a practically identical $\mathrm{EC}_{50}$ for sorafenib 

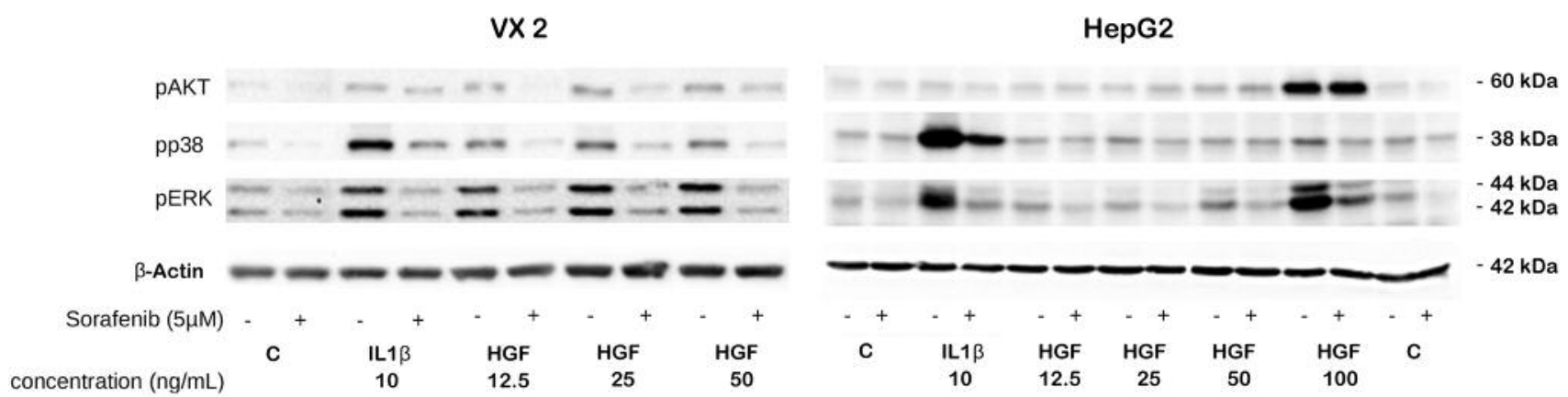

Figure 4. Dose response of kinase phosphorylation of VX2 and HepG2 cells to hepatic growth factor (HGF). Cells were grown to confluency, subjected to serum starvation for $24 \mathrm{~h}$ and then stimulated for $10 \mathrm{~min}$ with the indicated factors. Dimethyl sulfoxide was used as solvent control for sorafenib treatment.

toxicity for both cell types, and most of the growth factors used evoked comparable signaling responses in both.

Nevertheless, only HepG2 cells activated caspase 3/7, indicating apoptosis upon sorafenib exposure, whereas VX2 seems to execute cell death by another mechanism that we did not further determine in this study but which others suggest as being through autophagy (32).

The $\mathrm{EC}_{50}$ values for survival have been previously determined and our data $(1.8 \mu \mathrm{M})$ are within the published range. Liu et al. determined an $\mathrm{EC}_{50}$ value of $4.5 \mu \mathrm{M}$ for HepG2 cells, also after $72 \mathrm{~h}$ exposure, but used an luminescent ATP assay for determination of cell viability (26). Pascale et al. found higher values of 10.4 for VX2 and $9.0 \mu \mathrm{M}$ for HepG2 after 72-h incubation with sorafenib and determined the cell number indirectly by measuring total cellular protein (25). We assume that these differences can be attributed to different experimental approaches, including not only the method to determine proliferation and viability, but also different media compositions and serum batches.

An important feature for a cancer cell in its niche is the possibility to respond to various proliferative or inflammatory factors provided by the microenvironment or via the bloodstream. The mechanism of sorafenib as a broad-specificity kinase inhibitor is to block such signals in order to inhibit proliferation or cause cell death. Earlier publications have often focused on activation of the ERK pathway by HGF or serum factors (26) and inhibition of ERK phosphorylation by sorafenib; we herein intended to extend these data to other factors important for HCC and additional signaling pathways. Our growth factor set contained PDGF-AB, VEGF, IL1 $\beta$, insulin and HGF. PDGF-AB is secreted by HCC cells and responsible for their growth (33). HCC is an inflammation-associated cancer, therefore IL1 $\beta$ signaling is important for tumorigenesis by e.g. up-regulating gankyrin (34). Liver cells are typical targets for insulin and HCC risk is higher in insulin-resistant diabetic patients $(35,36)$. VEGF is well known for its effects on vascularization of tumors. In patients with HCC, the VEGFA gene is often amplified, which triggers secretion of HGF. Patients with HCC with VEGFA gene amplification are reportedly especially sensitive to sorafenib (37). Last but not least, HGF is a multifunctional cytokine which modifies proliferation, motility and morphogenesis of cells by its interaction with its receptor also known as cellular mesenchymal-epithelial transition (cMET) (38).

With stimulated and unstimulated cells, we determined the concentration of sorafenib which effectively blocked ERK phosphorylation. This concentration was comparable in both cell lines $(5 \mu \mathrm{M})$, which was consistent with the also virtually identical effective toxic concentration of the drug.

Although the $\mathrm{EC}_{50}$ values for sorafenib in vitro have been determined to be in the nanomolar range i.e. 4 to $90 \mathrm{nM}$ against rearranged during transfection (RET) rat fibrosarcoma-1 (cRAF) and the VEGFR, working concentrations of sorafenib in cell cultures were in the low micromolar range (39), which our data are consistent with.

The responsiveness to growth factors reflects the expression of the respective receptors and the sensitivity of the coupled signaling cascades. HepG2 cells showed no detectable response to PDGF-AB and VEGF. When comparing the responses of the cell lines, we observed a generally higher sensitivity of VX2 for most factors. Interestingly, VX2 also very sensitively responded to HGF but in contrast to HepG2 cells, the response to insulin was rather weak. The latter result is consistent with the importance of insulin signaling for liver cells.

In VX2 cells, sorafenib was able to block growth factorinduced phosphorylation of AKT, ERK and p38 MAPK regardless of the stimulant. In contrast, sorafenib was ineffective in blocking insulin- and FCS-induced AKT 
phosphorylation in HepG2 cells. In both cell lines, no reduction of IL1 $1 \beta$-induced phosphorylation of IкB $\alpha$ and p65 (data not shown) was observed. This was expected as these signals are upstream of ERK and p38 in the IL $1 \beta$ receptor cascade. Interestingly, IL $1 \beta$ was among the strongest inducers of p38-MAPK and ERK phosphorylation in HepG2 cells, and these responses were effectively diminished by sorafenib in both HepG2 and in VX2 cells.

These in vitro data strongly suggest an important role of inflammatory signaling via Toll-like receptors such as the IL1 $\beta$ receptor for HCC. Indeed, one downstream kinase of the IL1 $\beta$ receptor, interleukin receptor-associated kinase 1 (IRAK1) is up-regulated in many HCCs and cell lines derived from HCCs $(34,40)$, suggesting that interleukin signaling may be a target for HCC therapy. As sorafenib effectively inhibits downstream activation of ERK and $\mathrm{p} 38$ by IL1 $\beta$, this might contribute to the effects of this drug on HCC.

Taken together, we demonstrated several common features of the VX2 and HepG2 cellular models, justifying the use of VX2 cells in rabbit in vivo studies. However, as distinct differences were also observed, the results obtained in such investigations should always be interpreted with care.

\section{References}

1 Bruix J, Reig M and Sherman M: Evidence-based diagnosis, staging, and treatment of patients with hepatocellular carcinoma. Gastroenterology 150: 835-853, 2016.

2 Llovet JM, Di Bisceglie AM, Bruix J, Kramer BS, Lencioni R, Zhu AX, Sherman M, Schwartz M, Lotze M, Talwalkar J, Gores GJ and Panel of Experts in HCC-Design Clinical Trials: Design and endpoints of clinical trials in hepatocellular carcinoma. J Natl Cancer Inst 100: 698-711, 2008.

3 Mazzaferro V, Regalia E, Doci R, Andreola S, Pulvirenti A, Bozzetti F, Montalto F, Ammatuna M, Morabito A and Gennari L: Liver transplantation for the treatment of small hepatocellular carcinomas in patients with cirrhosis. N Engl J Med 334: 693699, 1996.

4 Wang Y, Luo Q, Li Y, Deng S, Wei S and Li X: Radiofrequency ablation versus hepatic resection for small hepatocellular carcinomas: a meta-analysis of randomized and nonrandomized controlled trials. PloS One 9: e84484, 2014.

5 Hu HT, Kim JH, Lee L-S, Kim K-A, Ko G-Y, Yoon H-K, Sung K-B, Gwon DI, Shin JH and Song H-Y: Chemoembolization for hepatocellular carcinoma: multivariate analysis of predicting factors for tumor response and survival in a 362-patient cohort. J Vasc Interv Radiol 22: 917-923, 2011.

6 Llovet JM, Real MI, Montaña X, Planas R, Coll S, Aponte J, Ayuso C, Sala M, Muchart J, Solà R, Rodés J, Bruix J and Barcelona Liver Cancer Group: Arterial embolisation or chemoembolisation versus symptomatic treatment in patients with unresectable hepatocellular carcinoma: a randomised controlled trial. Lancet Lond Engl 359: 1734-1739, 2002.

7 Lo C-M, Ngan H, Tso W-K, Liu C-L, Lam C-M, Poon RT-P, Fan S-T and Wong J: Randomized controlled trial of transarterial lipiodol chemoembolization for unresectable hepatocellular carcinoma. Hepatol Baltim Md 35: 1164-1171, 2002.
8 Llovet JM, Ricci S, Mazzaferro V, Hilgard P, Gane E, Blanc JF, de Oliveira AC, Santoro A, Raoul J-L, Forner A, Schwartz M, Porta C, Zeuzem S, Bolondi L, Greten TF, Galle PR, Seitz J-F, Borbath I, Häussinger D, Giannaris T, Shan M, Moscovici M, Voliotis D, Bruix J and SHARP Investigators Study Group: Sorafenib in advanced hepatocellular carcinoma. N Engl J Med 359: 378-390, 2008.

9 Ricke J, Bulla K, Kolligs F, Peck-Radosavljevic M, Reimer P, Sangro B, Schott E, Schütte K, Verslype C, Walecki J, Malfertheiner P and SORAMIC study group: Safety and toxicity of radioembolization plus sorafenib in advanced hepatocellular carcinoma: analysis of the European multicentre trial SORAMIC. Liver Int Off J Int Assoc Study Liver 35: 620-626, 2015.

10 Kim YB, Park YN and Park C: Increased proliferation activities of vascular endothelial cells and tumour cells in residual hepatocellular carcinoma following transcatheter arterial embolization. Histopathology 38: 160-166, 2001.

11 Wang B, Xu H, Gao ZQ, Ning HF, Sun YQ and Cao GW: Increased expression of vascular endothelial growth factor in hepatocellular carcinoma after transcatheter arterial chemoembolization. Acta Radiol Stockh Swed 49: 523-529, 2008.

12 Lencioni R, Llovet JM, Han G, Tak W-Y, Yang J, Leberre M-A, Niu W, Nicholson K, Meinhardt G and Bruix J: Sorafenib or placebo in combination with transarterial chemoembolization (TACE) with doxorubicin-eluting beads (DEBDOX) for intermediate-stage hepatocellular carcinoma (HCC): Phase II, randomized, double-blind SPACE trial. J Clin Oncol 30: suppl 4; abstr LBA154^, 2012.

13 Liu L, Chen H, Wang M, Zhao Y, Cai G, Qi X and Han G: Combination therapy of sorafenib and TACE for unresectable HCC: a systematic review and meta-analysis. PloS One 9: e91124, 2014.

14 Chatziioannou AN, Siskos AP, Loxas D, Kavatzas N, Agrogiannis G, Fokas D, Malagari K, Kostomitsopoulos NG, Tsigkou $\mathrm{O}$ and Tamvakopoulos C: Transarterial embolization with sorafenib in animal livers: a pharmacokinetics study. J Vasc Interv Radiol JVIR 24: 1657-1663.e1, 2013.

15 Gaba RC, Yap FY, Martinez EM, Li Y, Guzman G, Parvinian A, van Breemen RB and Kumar N: Transarterial sorafenib chemoembolization: preliminary study of technical feasibility in a rabbit model. J Vasc Interv Radiol 24: 744-750, 2013.

16 Parvinian A, Casadaban LC, Hauck ZZ, van Breemen RB and Gaba RC: Pharmacokinetic study of conventional sorafenib chemoembolization in a rabbit VX2 liver tumor model. Diagn Interv Radiol Ank Turk 21: 235-240, 2015.

17 Zhang L, Liu F-Y, Fu J-X, Duan F, Fan Q-S and Wang M-Q: Hepatic arterial administration of sorafenib and iodized oil effectively attenuates tumor growth and intrahepatic metastasis in rabbit VX2 hepatocellular carcinoma model. Int J Clin Exp Pathol 7: 7775-7781, 2014.

18 Seidensticker M, Streit S, Nass N, Wybranski C, Jürgens J, Brauner J, Schulz N, Kalinski T, Seidensticker R, Garlipp B, Steffen I, Ricke J and Dudeck O: Modified transarterial chemoembolization with locoregional administration of sorafenib for treating hepatocellular carcinoma: feasibility, efficacy, and safety in the VX2 rabbit liver tumor model. Diagn Interv Radiol Ank Turk 22: 378-384, 2016.

19 Deng G, Zhao D-L, Li G-C, Yu H and Teng G-J: Combination therapy of transcatheter arterial chemoembolization and arterial administration of antiangiogenesis on VX2 liver tumor. Cardiovasc Intervent Radiol 34: 824-832, 2011. 
20 Geschwind JF, Artemov D, Abraham S, Omdal D, Huncharek MS, McGee C, Arepally A, Lambert D, Venbrux AC and Lund GB: Chemoembolization of liver tumor in a rabbit model: assessment of tumor cell death with diffusion-weighted MR imaging and histologic analysis. J Vasc Interv Radiol JVIR 11: 1245-1255, 2000.

21 Aravalli RN, Steer CJ, Sahin MB and Cressman ENK: Stem cell origins and animal models of hepatocellular carcinoma. Dig Dis Sci 55: 1241-1250, 2010.

22 Rous P and Beard JW: A virus-induced mammalian growth with the characters of a tumor (the Shope rabbit papilloma): I. The growth on implantation within favorable hosts. J Exp Med 60: 701-722, 1934.

23 Pauser S, Wagner S, Lippmann M, Pohlen U, Reszka R, Wolf $\mathrm{KJ}$ and Berger G: Evaluation of efficient chemoembolization mixtures by magnetic resonance imaging therapy monitoring: an experimental study on the VX2 tumor in the rabbit liver. Cancer Res 56: 1863-1867, 1996.

24 Ko YH, Pedersen PL and Geschwind JF: Glucose catabolism in the rabbit VX2 tumor model for liver cancer: characterization and targeting hexokinase. Cancer Lett 173: 83-91, 2001.

25 Pascale F, Bedouet L, Baylatry M, Namur J and Laurent A: Comparative chemosensitivity of VX2 and HCC cell lines to drugs used in TACE. Anticancer Res 35: 6497-6503, 2015.

26 Liu L, Cao Y, Chen C, Zhang X, McNabola A, Wilkie D, Wilhelm S, Lynch $\mathrm{M}$ and Carter C: Sorafenib blocks the RAF/MEK/ERK pathway, inhibits tumor angiogenesis, and induces tumor cell apoptosis in hepatocellular carcinoma model PLC/PRF/5. Cancer Res 66: 11851-11858, 2006.

27 Nass N, Vogel K, Hofmann B, Presek P, Silber R-E and Simm A: Glycation of PDGF results in decreased biological activity. Int J Biochem Cell Biol 42: 749-754, 2010.

28 Ruhs S, Nass N, Somoza V, Friess U, Schinzel R, Silber R-E and Simm A: Maillard reaction products enriched food extract reduce the expression of myofibroblast phenotype markers. Mol Nutr Food Res 51: 488-495, 2007.

29 Nass N, Brömme H-J, Hartig R, Korkmaz S, Sel S, Hirche F, Ward A, Simm A, Wiemann S, Lykkesfeldt AE, Roessner A and Kalinski T: Differential response to $\alpha$-oxoaldehydes in tamoxifen resistant MCF-7 breast cancer cells. PloS One 9: e101473, 2014.

30 Schneider CA, Rasband WS and Eliceiri KW: NIH Image to ImageJ: 25 years of image analysis. Nat Methods 9: 671-675, 2012 .
31 Nass N, Sel S, Ignatov A, Roessner A and Kalinski T: Oxidative stress and glyoxalase- 1 activity mediate dicarbonyl toxicity in MCF-7 mamma carcinoma cells and a tamoxifen resistant derivative. Biochim Biophys Acta, 2016.

32 Prieto-Domínguez N, Ordóñez R, Fernández A, García-Palomo A, Muntané J, González-Gallego J and Mauriz JL: Modulation of autophagy by sorafenib: effects on treatment response. Front Pharmacol 7: 151, 2016.

33 Ma Y, Han C-C, Li Y, Wang Y and Wei W: Insulin-like growth factor-binding protein-3 inhibits IGF-1-induced proliferation of human hepatocellular carcinoma cells by controlling bFGF and PDGF autocrine/paracrine loops. Biochem Biophys Res Commun 478: 964-969, 2016.

34 Su B, Luo T, Zhu J, Fu J, Zhao X, Chen L, Zhang H, Ren Y, Yu

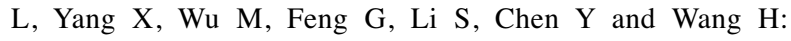
Interleukin-1 $\beta /$ Iinterleukin-1 receptor-associated kinase 1 inflammatory signaling contributes to persistent Gankyrin activation during hepatocarcinogenesis. Hepatol Baltim Md 61: 585-597, 2015.

35 Zoller $\mathrm{H}$ and Tilg $\mathrm{H}$ : Nonalcoholic fatty liver disease and hepatocellular carcinoma. Metabolism 65: 1151-1160, 2016.

36 Mazzoccoli G, Miele L, Oben J, Grieco A and Vinciguerra M: Biology, epidemiology, clinical aspects of hepatocellular carcinoma and the role of sorafenib. Curr Drug Targets 17: 783-799, 2016.

37 Llovet JM: Focal gains of VEGFA: candidate predictors of sorafenib response in hepatocellular carcinoma. Cancer Cell 25: 560-562, 2014.

38 Fajardo-Puerta AB, Mato Prado M, Frampton AE and Jiao LR: Gene of the month: HGF. J Clin Pathol 69: 575-579, 2016.

39 Mao W-F, Shao M-H, Gao P-T, Ma J, Li H-J, Li G-L, Han B-H and Yuan C-G: The important roles of RET, VEGFR2 and the $\mathrm{RAF} / \mathrm{MEK} / \mathrm{ERK}$ pathway in cancer treatment with sorafenib. Acta Pharmacol Sin 33: 1311-1318, 2012.

40 Li N, Jiang J, Fu J, Yu T, Wang B, Qin W, Xu A, Wu M, Chen $\mathrm{Y}$ and Wang $\mathrm{H}$ : Targeting interleukin-1 receptor-associated kinase 1 for human hepatocellular carcinoma. J Exp Clin Cancer Res CR 35: 140, 2016.
Received November 15, 2016

Revised December 5, 2016

Accepted December 6, 2016 